\title{
The Experimental Foundations of Galen's Teleology ${ }^{1}$
}

\section{Christopher $\mathbb{E}$. Cosans*}

When did science first acquire an experimental foundation? Conventional wisdom directs our attention to the 17th century. Dear, for example, defines the "modern understanding of "experiment" as a discrete, contrived, and reported event fit for use in establishing knowledge-claims about nature' and argues that the use of 'experiment emerged textually in the seventeenth century'. ${ }^{2}$ During the 17 th century an increasing desire to ground claims in procedures performed at a specific place and time sparked the rise of a new literary style: the research report. While the actual procedure might be a part of an experiment, this mere 'spatiotemporally defined region cannot be an experimental event without its constitution as such in the account'. ${ }^{3}$ It is not enough for a scientist to perform a contrived manipulation of nature, he must render his action public by reporting it as a discrete event with speech. In his careful study of the Royal Society's role in this rhetorical shift, Dear notes that Boyle establishes the experimental foundation of his claims 'not only by his careful recounting of the facts, but also by his use of the first person, active voice'. ${ }^{4}$ By contrast, the texts of ancient natural philosophers ground knowledge on more general and less personal 'statements about how things behave in the world'. ${ }^{5}$ Ancient scientists built up elaborate accounts of nature with little or no concern about grounding their theories on experimental foundations.

In the following paper, I would like to turn the clock back, and explore the possibility that at least one ancient philosopher of nature may be considered an *Department of Philosophy, George Washington University, Washington, D.C. 20052, U.S.A. Received 28 June 1995; in revised form 23 Jantary 1996.

${ }^{1}$ The following paper is part of a larger inquiry into how anatomy began. Other papers from this study include 'The Platonic Origins of Anatomy', Perspectives in Biology and Medicine 38 (1995) 581-596, and 'Galen's Critique of Rationalist and Empiricist Anatomy', Journal of History of Biology 30 (1997), 35-54.

${ }^{2} \mathrm{P}$. Dear, Narratives, Anecdotes, and Experiments: Turning Experience into Science in the Seventeenth Century', in P. Dear (ed), The Literary Structure of Scientific Argument (Philadelphia: University of Pennsylvania Press, 1991), pp. 135-163, see p. 146.

${ }^{3}$ Ibid., p. 137.

${ }^{4} \mathrm{P}$. Dear, 'Totius in verba: Rhetoric and Authority in the Early Royal Society', Isis 76 (1985), 145-161, see p. 152 .

sibid., p. 148 .

PII: S0039-3681(96)00005-2 
experimenter in the fullest sense. In contrasting the Anatomical Procedures with his earlier Usefulness of the Parts, Galen tells us that he writes the Procedureshis second comprehensive overview of body-in order that the student of nature can observe for himself each aspect of the body which Galen had

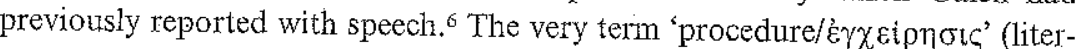
ally 'in-handing') connotes a hands-on approach to the subject. After guiding the reader through a full dissection of a monkey in books I-..V of Anatomical procedures, Galen devotes much of the remaining work to more detailed and focused studies of particular systems. When describing his procedures, he uses not only the first person, but also the second person pronoun and verb. Galen constantly calls for 'you' the reader to share these experiences by repeating the procedures yourself. He sees anatomical practice as freeing the student of nature from dependence on the doctrines of other contemporary physicians and philosophers who either ignore anatomical manipulation or put undue emphasis on theoretical speculation. ${ }^{7}$ One must not base his beliefs about nature on general statements he reads in a book, but on direct observations from opening, examining and manipulating the body for oneself.

Of course, an experimental scientist does not merely manipulate nature, he does this as a scientist. Since the dawn of civilization, empirics from cooks to physicians have been trying out various operations so as to learn how to achieve desired ends. The scientist, however, alters nature as part of a more theoretical inquiry into her order. Instead of seeking the mere powers of a craftsman, the student of nature strives first to obtain the understanding of a philosopher. ${ }^{8}$ With wisdom as his goal, the experimental philosopher embarks

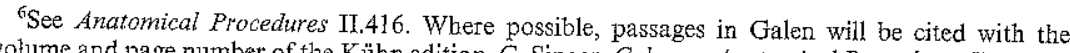
volume and page number of the Kühn edition. C. Singer, Galen on Anatomical Procedures (London: Oxford University Press, 1956), p. 238, argues that the Anatomical Procedures was begun around 177 A.D. and the Usefulness of the Parts was written between 169 and 175. At On the Order of My Own Books, in I. Mueller (ed.), Claudii Galeni Pergameni Scripta Minora (Adolf Hakkert: Amsterdam, 1967), vol. 2, pp. 80-90, XIX.54, Galen directs his reader to study the practices outlined in the Procedures before turning to his more theoretical writings.

'I explore the extent to which Galen's anatomical method responds to the Rationalist and Empiricist attitudes towards the body in Cosans, 1997, op. cit., note 1. Galen portrays Rationalists as believing that anatomical experiments give knowledge about the ultimate reality of the body which contributes to medicine; they generally advance mechanical theories about the body. The Empiricists reject this attempt to base medicine on experimentally derived theories because they deny dissection and vivisection can reveal unmanifest entities and processes within the living organism. In response, Gaien advances a critical anatomy which avoids the extremes of both epistemologies, and finds inspiration from the 'Ancients', who wrote before the RationalistEmpiricist argument, for an empirical realism. While he advocates the use of experimental science, Galen shies away from being overly theoretical about anatomy. Interestingly enough, I. Hacking, Representing and Intervening (Cambridge: University Press, 1983), p. 247-8, argues that Bacon advances his vision of experimental science in response to the Empirics and Dogmatic Theoreticians of the 17 th century. ${ }^{8}$ This seems to have especially been the case during antiquity when G. E. R. Lioyd notes that
science was seen as an end in itself: for it was evidently not seen, by society in general or even by notable individuals within it, as a means to some other desirable end" "Science and Morality in Greco-Roman Antiquity', in Methods and Problems in Greek Science (Ccince and Morality in University Press, 1991), pp. 352-371, see p. 353. on a open-ended inquiry where manipulation may lead to new understanding, which in turn may lead to further manipulations and discoveries. By providing the student a hands-on intimacy with the body, Galen sees experimental biology as establishing a deeper understanding of and respect for its natural processes. Anatomical practice allows anyone to observe the living organism not as an undirected agglomeration, but as a being with parts meticulously organized for their function in the whole.

\section{Galen's Vivisection Experiments}

Galen especially seems to advocate discrete and contrived experiments as a foundation of knowledge in bis use of vivisection procedures. In his careful study of early anatomical experiments, von Staden argues that the Hellenistic generation of physicians failed to use their experiments systematically enough to fully ground medicine; when challenged by medical Empiricism, experimental medicine witbered away. ${ }^{9}$ With an awareness of the difficulties raised by the Empiricists, Galen seeks to use and report anatomical procedures as objective practices by which anyone can establish facts about the body. He often recounts refuting some of his contemporaries by presenting them with a living organism and tben demonstrating the problems in their theories witb public experiments. ${ }^{10}$ When outlining one vivisection procedure Galen states his goal has been to write about it so clearly "that someone diligent will be able to perform completely the above anatomical practice anytime working by himself'. 11 Repeatability as such is thus crucial to any given event being an anatomical procedure. Rather than providing the reader with specific facts (or statements) about anatomy, Galen's text directs the student of nature on how to recreate critical observations for himself. A three step pattern of study and self-training emerges: first dissect the structures of interest from parts obtained from the butcher; then dissect the structures in a whole cadaver of the animal; and finally manipulate the structures in a living creature.

In order to prepare for vivisection, the student must repeat each step on as many animals as necessary to obtain the skill needed for the next stage of manipulation. Aithough the body's delicate nature requires the biologist to be extremely persistent, Galen believes the reward to be ample:

It is indeed shameful and disgraceful that everyone is accustomed to bring themselves to voyage across the great expanses of the sea for the sake of wealth, and thereby to

${ }^{9} \mathrm{H}$. von Staden, 'Experiment and Experience in Heltenistic Medicine', Bulletin of the Institute of Classical Studies 22 (1975), 178-199.

${ }^{10}$ See for example Anatomical Procedures II.636-39 and II.641-3. For the cultural context of anatomical experiments in antiquity see H. von Staden, 'The Discovery of the Body', Yale Journal of Biology and Medicine 65 (1992), 223-241.

${ }^{11}$ Galen, Anatomical Procedures in C. G. Kühn (ed.), Galeni Opera Omnia (Hildesheim, 1965), vol. 2, pp. 215-706, see II.694. In order to insure consistent terminology, all translations from the Greek will be my own. 
endure very great hardships, but as regards the knowledge and the understanding of the nature of things, it is their custom not to undertake the repetition of the same task time after time. ${ }^{12}$

A hunger for knowledge thus drives the biologist to develop experimental techniques for exploring the body. Because of the high value he places on knowledge, Galen argues 'that the best physician is also a philosopher'. ${ }^{13}$ His opposition of those many who seek wealth with those few who seek knowledge harkens back to the Republic, one of the Platonic works about which Galen wrote. ${ }^{14}$ In contrasting man's hungers for wisdom, honor, and material gain, Plato claims that aspect of us which 'always strives towards knowing what truth is, also cares the least of these about money and reputation'.15 Given the difficulties of inquiring into the truth of things, the lover of wisdom must also have a love of work $/ \varphi \imath \lambda$ o ovía. $^{16}$

In the case of embryology, Galen guides the natural philosopher through a sequence of progressively more arduous manipulations. After discussing a folk practice of removing the gonads from female pigs, he gives the procedure for dissecting the uterus and gonads in a dead goat. In order to prepare for vivisection, the student must then dissect a pregnant animal and master the basic structural relations of the womb and the fetus. ${ }^{17}$ Galen advocates vivisection experiments in order to study how and when an individual's life begins. He reports that some sophists had described the fetus as merely another

${ }^{12}$ Galen, On Anatomical Procedures the Latter Books, W. Duckworth (trans), M. Lyons and B. Towers (eds) (Cambridge: University Press, 1962), p. 214. Duckworth translates books X-XV of Anatomical Procedures, which have been lost in the original Greek but survive in a 9 th century Arabic see I. Ormos, 'Bemerkunalysis of how Galen's anatomical language was translated into Sektion toter Lebewesen" ", in I. Kollesch editorischen Bearbeitung der Galenschrift "Über die (Stuttgart: Franz Steiner ', in J. Kollesch and D. Nickel (eds), Galen und das Hellenistische Erbe (Stuttgart: Franz Steiner Verlag, 1993), pp. 164-172. Galen stresses the importance of persistent ${ }_{13}$ Galen education at On the Order of My Own Books, op. cit., note 6, XIX.59-60.

Pergameni Scripta Minora (Adolf Hakkert: Amsterdam, 1967) I. Mueller (ed.), Claudii Galeni ${ }^{14}$ In his overview of Galen's affection for Aunsterdam, 1967), П, 1-8.

Republic, Cratylus; Sophist, Statesman, Parmenides, Lacy notes that Galen wrote synopses of the Republic, Cratylus, Sophist, Statesman, Pammenides, Euthydemus, and Laws (P. De Lacy, 'Galen's Blatonism', American Journal of Philosophy 93 (1972), 27-39, see p. 31). Galen at On My Own Books, op. cit., note 6, XIX.46, lists nine works pertaining to Plato's philosophy including works on tripartite psychology and commentaries on the Timaeus and Philebus. Although Galen seems to have a special respect for Plato, he does not hesitate from considering the ideas of other philosophers like Aristotle in the search for truth. In Cosans, forthcoming, op. cit., note 1, I explore the way Galen rejects sects, and freely uses various classical works to advance his thought beyond the parochial concerns of his contemporaries. For a rich treatment of Galen's response to Plato see $C$. Larrain, Galeni De Eis Quae Medice Dicta Sunt in Platonis Timaeo (Stuttgart: B. G. Teubner, 1992). ${ }^{15}$ Plato, The Republic, edited Greek text with translation by P. Shorey (Cambridge, Mass: Horvard University Press, 1935), vol. 2, $581 \mathrm{~b}$.

Ibid., 535d. At On Habits, in I. Mueller (ed.), Claudii Galeni Pergameni Scripta Minora (Adolf Hakkert: Amsterđam, 1967), vol. 2, pp. 9-31, p. 12, Galexn claims that on must search for a cause

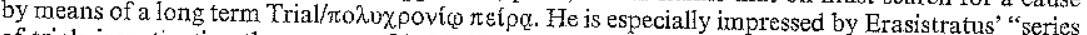
of trials investigatimg the powers of habits", p. 16

Ormos, op. cit., note 12, p. 171 reports that in his work On the Dissection of Dead Animals, which is extant in Arabic, Galen argues that anatomists must always precede vivisection with part of the mother. Experimental embryology, however, demonstrates that the fetus in fact moves by its own power. The experimenter can observe especiaily well two kinds of activities in utero: the pulse motion that originates from the beart, and voluntary motion that originates from the brain. Galen recommends investigating the former by gently grasping the umbilical cord without disturbing the fetus, and comparing its pulse with that of the mother's abdominal aorta. In order to investigate the voluntary motion of the fetus, the anatomist can 'stimulate it so that it jerks and raises itself upwards'. ${ }^{18}$ Galen finds it especially noteworthy that one can observe the young animal move its chest although it does not breathe any air into its lungs.

Galen prescribes some of the most detailed experiments on the cardiovascular system that would be performed until the Renaissance. Working at the very dawning of anatomy, Aristotle indicates that he observes the motion about a chameleon's heart and examines the effect of removing the heart in the case of tortoises. His most contrived procedure seems to be the use of starvation and strangulation in the preparation of cardio-vascular dissections. In the Hellenistic generation, physicians like Erasistratus use even more sophisticated contrivances, as in the case of inserting a tube into arteries in order to determine if arterial walls or pneuma traveling within causes the pulse. ${ }^{19}$ Writing four centuries later Galen manipulates even more subtle aspects of the body. In maneuvering around the body, he is especially careful with the body's aspect that 20th century biologists designate as the celom. Galen offers detailed instructions on how to expose the heart by cutting just the pericardium, while not puncturing the pleura and collapsing the lungs. ${ }^{20}$ Having exposed the throbbing heart, the biologists can perform a wide variety of procedures from applying physical pressure, to ligating various vessels, to even feeding and sustaining the animal for some time with its heart exposed.

Galen makes even greater use of experimental techuique when refuting Erasistratus' theory that only pneuma is naturally present in the arteries. While Galen wrote a small treatise inquiring If Blood is Naturally Contained in the Arteries, he also attempts to preserve his experimental proofs for posterity by outlining them in the Anatomical Procedures. Erasistratus' followers insist that any blood seen when one cuts into an artery is an experimental artifact from the unnatural escape of pneuma and entrance of blood from veins. This puts great pressure on Galen to contrive manipulations that would somebow prevent the influx and isolate the arteries' undisturbed state. To do so, he exposes an extended length of the aorta and places ligatures around the artery at two

${ }^{18}$ Duckworth transiation, op. cit., note 12, p. 122.

${ }^{19}$ For excellent logical analysis of this experiment see von Staden, op. cit., note 9, pp. 182-183, For an overview of ancient theories of the cardio-vascular system see C. Harris, The Heart and Vascular System in Ancient Greek Medicine (Oxford: Clarendon Press, 1973).

${ }_{20}$ At Anatomical Procedures I.628-31, Galen describes three different ways of exposing the heart for examination. 
distant places. After tightening the ligatures simultaneously, he cuts open the closed-off section of the artery to see if it contains blood. ${ }^{21}$ The presence of blood does not satisfy all 'pneuma only' tbeorists, however. Galen reports one person who asserts that blood leaked into the aorta from the opening of minor arteries, and that if the ligatures were placed around a superficial artery and the animal allowed a week to recover, then the arteries would turn out to be empty. While this theorist simply describes the procedure in speech, Galen reports actually implementing it in deed. Whether performed on goats, sheep, or cows, the arteries turn out to contain blood. ${ }^{22}$

Although Galen performs experiments on many aspects of the body, none surpasses the sophistication of his work on the neuro-muscular system. In response to Aristotelians and Stoics, he seeks to establish that sensation and reasoning emanate not from the heart but from the brain. He carefully defines how nerves connect specific muscles the brain, and enable it to thus control locomotion. Such a detailed understanding would even have practical implications for preserving his surgery patient's capacities in the clinic. One especially intricate set of procedures are those that establish the role of intercostal nerves and muscles in respiration. ${ }^{23}$ He reports his teachers as attributing the body's capacity to exhale and thus vocalize mostly to our diaphragm. ${ }^{24}$ Yet, they were aware that the thoracic wall also plays at least a minor role. Galen indicates that they would make incisions in the thoracic wall of a pig and observe the loss of its capacity to breathe and squeal. They also observe that if the incision is then patched up, 'the animal instantly breathes again and cries'. ${ }^{25}$ Galen builds upon this knowledge by seeking to isolate those specific aspects of the body by which the thorax makes its contribution. Because of the smallness of the first and last intercostal spaces, he suggests that the philosopher of nature concentrate on the middle nine. After getting extensive practice on dead animals, the biologist can turn his scalpel on the living. A simple procedure is to sever the muscles of the middle nine intercostal spaces while sparing the pleura, and then to observe the animal's inability to exhale.

In order to execute a really spectacular demonstration, however, Galen focuses upon the small but potent intercostal nerves. Carefully opening the intercostal space close to the spinal cord, one should use a hook to gently lift up its nerve and loosely insert a wool thread around it. After placing threads around the nerves of all nine spaces on both sides, they can simultaneously be tightened and the animal will lose its capacity to breathe. Galen observes that

${ }^{21}$ See Anatomical Procedures II.643.
${ }^{22}$ Ibid., Il.644-5.

${ }^{23} \mathrm{C}$. Larrain reports that given its mixed nature of being both controlled by the will and occurring naturally like the pulse, Galen finds the motion of respiration perplexing and explores it in On Puizzling Movements, "Galen, De Motibus Dubiis: die Lateinische Ubersetzung des Niccolo da Reggio', Traditio 49 (1994), 171-233, see pp. 179-181.

${ }^{25}$ Anatomical Procedures, Küln text, op. cit., note 11, II.665. the animal 'screams when struck, then suddenly becomes silent upon the compressing of the nerves by the threads' ${ }^{26}$ In order to further demonstrate that the loss is due only to the specific manipulation of the nerves, simply loosen the threads and the function returns. The use of wool thus enables the biologist to apply pressure upon the nerves, which stops their activity without doing permanent damage. By using this basic technique all over the body, Galen establishes the manner in which nerves that ultimately branch off the brain and spinal cord contribute to the activities of the body's various muscles. Hankinson claims that Galen's anatomical procedures, 'lacking the ideas of experimental control and isolation', ${ }^{27}$ are not experiments in the fullest sense. Yet Galen's extra effort to ligate and restore nerves rather than simply severing them shows that he goes to great lengths to tease apart the artifacts of his procedures from real phenomena. By restoring function after ligation, Galen essentially controls for other factors and isolates the nerves' condition as the cause of the loss of muscular activity. ${ }^{28}$

Although the extent to which he advocates vivisection would no doubt horrify many of us, Galen is not as callous as he first seems. He clearly recognizes animal suffering. In his criticism of Stoic moral psychology, he rejects the idea that irrational animals do not have passions and desires. ${ }^{29}$ Throughout the Procedures he does not sanitize experimentation, but reports how the animals scream when cut open. Given this suffering, the philosopher of nature sbould not wantonly torture organisms. This is especially the case witb the animal closest to man--the monkey. The Simian vivisection 'is a batefully

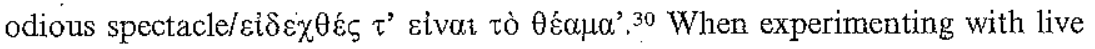
organisms, Galen argues that domestic animals like goats and pigs are similar enough to man that they can substitute for monkeys. Even in the case of these less human animals, not all possible vivisections are justified. When guiding the study of testicles, he tells the reader that 'it is superfluous to dissect the testicle of a living animal', ${ }^{31}$ since vivisection reveals neither new relations nor functions

${ }^{26} \mathrm{Ibid}$., II.669. Although this procedure will no doubt be quite alien to the 20 th century reader, there is something in her experience which indeed relates to the phenomenon explored by Galen. The numbness when one's leg falls asleep results from a loss of sensory function due the pressure on the sciatic nerve.

${ }^{27}$ R. J. Hankinson, 'Galen's Anatomical Procedures', in W. Haase and H. Temporini (eds) Aufstieg und Niedergang der Römischer Welt (Berlin: Walter De Gruyter, 1994), part II: volume

37.2 , pp. 1834-1855, see p. 1841 .
28 The procedure of tying arteries off with two ligatures, discussed above, provides another example of Galen's effort to control for experimental artifacts and isolate the body's natural state. For more on the use of experimental controls in ancient science see von Staden, op. cit., note 9. ${ }^{29}$ See On the Doctrines of Hippocrates and Plato V.168

${ }^{30}$ Anatomical Procedures, Kühn text, op. cit., note 11, II.690. Galen also refers to the repulsiveness of sinian vivisection in the latter Arabic books at II. 15 and 85, Duckworth translation, op. cit, note 12

${ }^{31}$ Duckworth translation, op. cit., note 12, p. 124. Ormos, op. cit., note 12 , reports Galen as also claiming that careful study of the structural relations of cartilage, joints, and muscles of the larynx in dissection reveals more about its activity than a given vivisection procedure. 
that are not seen in the dead. Given the lack of justification, the animal should be spared. In many other cases, however, Galen does see the fundamental good of acquiring knowledge as outweighing the suffering of animals. Man simply cannot learn about nature by sitting in a comfortable armchair and reading stories. In order to ground biomedical thought in the body's reality and not on imitations in speech, we must unfortunately make a blood sacrifice.

\section{From Books to Bodies}

A self-conscious awareness about the limitations of books underlies the entire discourse of the Anatomical Procedures. Galen directs the student not simply to read Procedures' words as he would read the stories of Herodotus 'but to store in the memory each of the things seen, so you know the nature of all the body's parts exactly'. ${ }^{32}$ While Herodotus' narrative transports the reader's imagination to distant places and times, Galen's text directs the student of nature to acquire anatomical material and embed his fingers in the body's gooey presence. Galen makes a hard and fast distinction between the body as it appears in the real world, and the scientist's linguistic description of it. ${ }^{33} \mathrm{He}$ is especially explicit in the case of bones: 'I direct you to acquire exact experience with human bones, neither looking at them incidentally nor only reading from a book, not even ours'. ${ }^{34}$ Throughout the Anatomical Procedures, he expresses frustration with the limits of verbal description: "what is distinguished clearly by seeing or touching alone, it is impossible to teach exactly these things by speech', ${ }^{35}$ In urging the student to acquire empirical intimacy with the body, Galen spares none of the senses. His account of the heart even has the student learn the difference between heart and skeletal muscle by contrasting how each tastes! ${ }^{36}$ Galen's word wariness may have some relation to the traditional RationalistEmpiricist dispute. The Greek term ' $\lambda$ ó ${ }^{\circ} \zeta^{\prime}$ ' can be used to refer to both 'speech' and 'reason', and also serves as the root for the term 'Rationalist/o $\lambda o \gamma 1 \kappa o ́ s$ ' itself. ${ }^{37}$

${ }^{32}$ Galen, Anatomicarum Administrationum, books I-IV, Greek and Arabic text-edited by I. Garofalo (Leiden: E.J. Brill, 1986), II.393.

${ }^{33}$ Von Staden, 'Apud nos foediora verba: Celsus' teluctant construction of the female body', in G. Sabbah (ed.), Le latin médical. La constitution d'un langage scientifique (Publications de l'Universitè de Saint-Etienne, 1991), pp. 271-296, see p. 291, argues that Celsus on the other hand uses language to offer a fully 'textual construction of the female body'.

${ }^{34}$ Ibid., II.220. On a similar note, at On Habits, op. cit., note 16, p. 18, Galen credits Hippocrates and Erasistratus for basing their accounts of the disposition of habits not to what is found by word but what is learned from the things that are visibly apparent.

${ }^{35} \mathrm{~K}$ ühn text, op. cit., note 11 ,

${ }^{36}$ See Anatomical Procedures II.611-12. At the beginning of book XV, Gaten also uses the taste test to distingish brocedures 11.61 rom the substance of the brain and spinal cord, Duckworth ${ }^{37}$ For an excellent overiew $223-4$

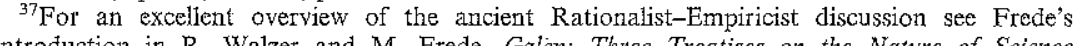
introduction in R. Walzer and M. Frede, Galen: Three Treatises on the Nature of Science approach to anatomy in Cosans, 1997, op. cit., note 1 .
In studying the Anatomical Procedures, Michael Frampton and I followed its directions for monkey dissection on a Macaca Mulatta. When used as a laboratory manual, it becomes clear that Galen intended for this book to be read not in an armchair, but at the workhench. The very language of the Procedures draws upon the body. Galen refers to many parts not with simple names but with long clauses that would be obscure or unintelligible if one does not have personal anatomical experience of the body. What Gray's Anatomy dubs the 'median vein of forearm', 38 Galen calls the vein 'extending along the middle of much of the forearm near the limb's surface and then meeting at the wrist with the artery that has an obvious pulse'. ${ }^{39}$ This expression relies not only on what dissection reveals in the depths of a monkey arm, but also upon the activity of the pbysician feeling his living patient's wrist. Such phrases thus assume anatomical practice to acquire their full meaning. When directing the student on how to expose the heart of a living organism, Galen tells the reader to use the cadavar of another animal in determining where he should cut; 40 a book in the modern tradition of Gray's would refer to a picture. His desire to report procedures as exactly as possible influences the very way in which Galen sings his epic. Galen tells the reader that he dictates his detailed anatomical observations and directions 'with the animal placed in front of me, while I am looking at the things about which I am talking'. ${ }^{41}$ This wedding of the student's act of learning with the trained biologist's observations allows scientific discovery to take on a timeless dimension and become a never ending process of inquiry.

Because no two bodies are exactly alike, the student must be ever prepared to see something new, and even different from what the book records. Structures will not always appear exactly as Galen describes. If the student sees something different from the text, Galen implores: 'it is necessary you do not condemn the things written by us until you yourself, just as we, have seen many bodies'. ${ }^{42}$ Since patients vary just like cadavers, an awareness of the possible ways a structure can vary from individual to individual enables the clinician to properly treat his particular patient's body. In a 20 th century effort to advance a philosophy of medicine that incorporates some insights from the ancient Greek physicians, Pellegrino and Thomasma call the problem of how theoretical knowledge can be applied to concrete, individual body-persons with

${ }^{38}$ Thirty-seventh edition, P. L. Williams, R. Warwick, M. Dyson, and L. H. Bannister (eds) (London: Churchill Livingstone, 1989), p. 806

${ }^{39}$ Garofalo text, op. cit., note 32 II 366.

${ }^{10}$ See Anatomical Procedures 11.606 and $\Pi .639$

${ }^{41}$ Duck Anatomical Procedures 11.606 and 11.639 . The Anatomical Procedures thus not only plays

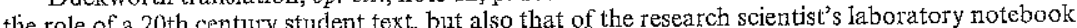
the role of a More than a millentum after the that occurred in the 16 th century after they were trated Latin.

2ing 32 II. 278 . 
therapeutic results' medicine's 'critical question'. ${ }^{43}$ In responding to this basic epistemological problem, Galen urges unrelenting practice on as many particular bodies as possible. He tells an anecdote of how after observing an unusual nerve in a monkey arm, he was able to testify for a fellow physician in a law suit by explaining the possibility that the patient's injury resulted from a similar variant nerve. In order to be ready for whatever variants might appear in the clinic, and avoid harming the patient in the first place, Galen advises the physician that 'a monkey arm must be dissected carefully by you often'.44 Anatomical knowledge does not consist of a written record of names and fixed places, but involves an active process of exploring the many ways the body appears in nature. Any claims of an anatomy book must be carefully considered in light of direct inspection of the body. From Galen's hands-on approach to biology, bodies and not books get the last word.

Given his skepticism towards written reports, Galen's experimental philosophy is more empirical than the Empiricists' approach to the body. The Empiricists ground medical practice in personal-observation/avitowía, their technical term. for an individual's memory that a particular treatment works frequently. In order to pass on new discoveries to future generations, Empiricists would make a written record which they call history/lotopí $\alpha$. Any future Empiricist could then study the records of history so be could treat conditions based upon his predecessors' experience. In Outline of Empiricism, Galen argues that 'it is necessary for us not to trust simply all the things written by our predecessors, but to establish thiem for ourselves before use'. 45 In a conmentary about Hippocrates, Galen puts it bluntly: 'because those disagreeing write on their own paper just as they wish, truth will be unclear to those inexperienced in anatomy'. ${ }^{46}$ While the Empiricists seem to have given a repeated personal-observation the status of empirical certainty once it enters their record of history, Galen continues to subject scientific reports to verification by each new generation. The stories handed down from previous generations only serve as a guide for obtaining personal experience. Galen's method of the Anatomical Procedures follows from this epistemological confidence in personal-observation over historical narratives. In his account of Empiricism, he expresses his own particular view of personal-observation. While earlier Empiricists considered personal-observation be an apprehension/

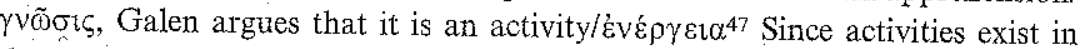
the very process of science, they cannot be fully captured within the confines

${ }^{43}$ E. Pellegrino and D. Thomasma, A Philosophical Basis of Medical Practice (New York: Oxford University Press, 1981), p. 85.

${ }^{44}$ Garofalo text, op. cit., note $32,1 \mathrm{I} .396$.

${ }^{45}$ Galen, An Outline of Empiricism, in Karl Deichgräber (trans. and ed.) Die griechiche

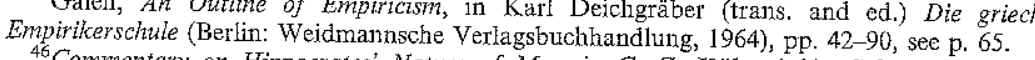

(Hidesheim 1965 ) Hippocrates' Nature of Man, in C. G. Kühn (ed.), Galeni Opera Omnia,

${ }^{4}$ See Outline of Empiricism, p. 47. of dusty old books. In contrast to many cookbook procedures of modern textbook science, a proper Galenic experiment never ends.

Galen's commitment to every student learning anatomy from the body itself leads him to one of his most infamous and criticized methods. Student physicians, he believes, should prepare for their surgical procedures on humans by dissecting monkeys. Before Galen, the Empiricists had established the practice of learning human anatomy strictly by examining wounds on buman patients. Galen argues, however, that monkey dissections can make an important supplement to such human sources of knowledge: dead monkeys squirm much less than wounded humans. Even if men and monkeys display some differences, "the monkey is the most similar to man of all animals with respect to viscera, muscles, arteries, veins, and nerves' ${ }^{48}$ Galen argues that the opportunities to observe wounds, as well as the occasional human dissection, establish the similarity of men and monkeys empirically. ${ }^{49}$ When referring to his more theoretical analysis in Usefulness of the Parts, he concludes from this similarity 'that the monkey is a humorous imitation of man'. ${ }^{50}$ In the last book of Anatomical Procedures, Galen suggests that such anatomical similarity between different species 'is evident and clear proof that it is through the operation of a single source of wisdom, which concerned itself with them, that all the bodily parts of animals have been built up and created'.51 While this passage echoes his earlier philosophy of nature in the Usefulness of the Parts, which we will discuss below, throughout the Procedures Galen stresses empirically observed similarities as the ultimate justification for the use of monkeys to study the human body. Rather than using the theory of his earlier work to ground his anatomical method, Galen seems to be quite careful to write the Procedures so as to provide an experimental foundation for his theory. Although he mentions the possibility of dissecting humans, such opportunities seem too rare for either mastering typical anatomy or learning variations. ${ }^{52}$ In discussing an opportunity that he had to dissect a German soldier, he notes that knowing monkey anatomy helps a great deal in observing human cadavers. Galen defends the use of monkeys by telling the reader that ' $I$ want you to have practiced much on them, so that if you ever happen upon a dissection of a human body, you will be prepared to lay bare each of the parts'. 53 The occasional dissection of human bodies, which were much less available in

${ }^{48}$ Garofalo text, op. cit., note 32, 11.219 .

${ }^{49}$ At Anatomical Procedures II.385-6 Galen discusses the use of wounds, and the dissection of criminals and exposed children to verify the similarity between man and monkey.

${ }^{50}$ Garofalo text, op. cit., note 32, II.416. For interesting analysis on Gaien's comparative anatomy see Garofalo, 'The Six Classes of Animals in Galen', in J. A. López Fèrez (ed.), Galeno: Obra, Pensamiento e Infuencia (Madrid: Universidad Nacional de Educacion a Distancia., 1988), pp. $73-87$.

Duckworth translation, op. cit., note 12, p. 228.

${ }^{52}$ Von Staden, op. cit., note 10, provides excellent analysis on the cuttural difficulties which

prevented extensive human dissection in the Roman. Empire.
${ }^{53}$ Garofalo text, op. cit., note 32, II.384-5. 
Galen's time than monkey cadavers, would be entirely inadequate for studying the body from Galen's hands-on approach.

In modern times Galen has come under criticism for basing the Anatomical Procedures, an introductory anatomical handbook, on monkey and not human anatomy. In his De Humani Corpons Fabrica, Vesalius, for example, provides the reader with an illustrated textbook that allows him to study the anatomical structure of the entire human body while not once dirtying the reader's fingers with either monkey or human cadavers. Indeed, the Epitome of this work introduces the student to the parts of the body by having him cut out, color, and manipulate pictures from a book. ${ }^{54}$ Today, many people hail Vesalius' work as the beginning of modern 'empirical' biology and medicine. Yet, in an important way, it offers a less empirical approach to anatomy than Galen. With the modern approach students might learn anatomy by reading words and looking at pictures that have been mechanically reproduced by printing presses. The naturally variable cadavers are thus displaced by neatly ordered book accounts of how the body should look. By contrast, Galen would have every student ground his anatomical understanding by first dissecting many monkeys and vivisecting other animals for himself, and then observing patients and the rare human cadaver.

In a peculiar way, Galen's wariness of the representations found in books, fits with his favorite philosopher's approach to learning. ${ }^{55}$ In the Republic, Plato's Socrates portrays the representations of poets and painters as being more remote from reality than even sensible objects. ${ }^{56}$ If the realm of the body imitates the Forms, then the pictorial and linguistic representations of modern books are imitations of imitations. Even if they are imitations in flesh, monkey bodies help one inquire into the human body's nature without becoming further removed from the world in which we live and learn. While animals and humans may differ, they have much more in common than either has with a two dimensional sheet of paper. In the Phaedrus, Socrates warns that reading books cannot substitute for the philosophical conversation between two living

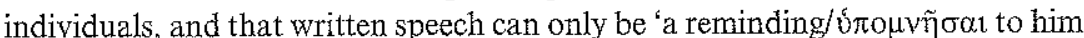
knowing that about which they were written'. ${ }^{57}$ At best, books can serve as a catalyst for a student's inquiry with his instructor. In his work on his own

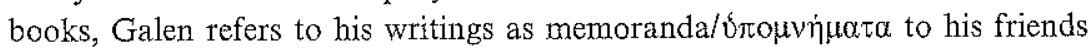
and students of conversations they have shared. ${ }^{58} \mathrm{He}$ opens the Procedures by

${ }^{54}$ A. Vesalius, The Anatomical Drawings of Andreas Vesalius (1543), edited and translated by

J. Saunders and C. O'Malley (New York: Bonanza Books, 1982), p. 220 .
${ }_{55}^{5}$ For Plato's specific approach to anatomy see Cosans, 1995, op. cit. note 1.

${ }^{55}$ For Plato's specific
${ }^{56}$ See Republic 5980.

${ }^{56}$ See Republic 5980.
${ }^{57}$ Plato, Enthyphro, Apology, Crito, Phaedo, Phaedrus, edited G
H. N. Fowler (Cambridge: Harvard University Press, 1982), 275d.

${ }^{58} \mathrm{See}$ On My Own Books XIX.10. Galen explicitly refers to the Phaedrus' account of speech at Commentary On Hippocrates' Nature of Man XV.5, and On the Doctrines of Hippocrates and Plato V.767-771. specifically referring to it as memoranda for experiments he had performed with colleagues, which will enable them and others repeat the activities. Aithough he writes the Procedures, Galen thus seeks to go beyond the paper and to stimulate his reader's active experimentation with nature..$^{59}$

\section{Philosophy with a Scalpel}

Galen sees anatomy not as a mere technique for cutting up the body, but as a way to practice philosophy. Writing at a time before science split off from the other areas of inquiry, he advances anatomical experimentation as an important method for grounding philosophical understanding. ${ }^{60}$ In considering basic questions about the soul, life, or nature, what firmer place could a philosopher begin? Galen builds up theoretical analysis from the foundation of dissection and vivisection extensively in the Anatomical Procedures' companion work the Usefulness of the Parts. ${ }^{61}$ Of the many lessons he draws from anatomical inquiry concerning the body, none stands out more than reverence for pature. As he rummages around the body, the philosopher witnesses countless structures fitting and working together in the most intricate fashion. Each instance drives home the case for nature's splendor:

For no one is so unperceptive/óvaíantos, that observing the proportioned place where bone has been carved out for the tendon about to pass by, he still inquires, kicks around, or ponders whether nature plans for the safety of the parts. ${ }^{62}$

The fine detail of the body's organization provides manifest proof of nature's skill to any unbiased observer, although perhaps not to the materialistic 'enemies of nature'. ${ }^{63}$ By advancing experimental philosophy, Galen confronts the materialist directly with the sweep of nature's purpose so that 'he loses sleep searching in order to criticize something that he has seen'. ${ }^{64}$

One such enemy of nature is the first century materialist Asclepiades of Bithynia, who describes 'the principles of everything that comes-to-be as

${ }^{59}$ Of course actively performing dissections and vivisections need not exclude also reading and discussing more theoretical books on anatomy. After outlining the contents of the Anatomical Procedures as giving the necessary beginning of anatomical study, Galen describes at length a very Procedures as giving the necssary' antomical texts at On My Own Books XIX. 25-30.

large book that he wrote on Marinus' anatomical texts at Oni Mpera Omnia (H-Tildesheim, 1965) ${ }^{60}$ At On Fetal Formation, in C. G. Kuhn (ed), Galent Opera Omstation about the hear IV.676-677, Galen criticizes the Stoics failing to give a proper from the things that are visibiy because they did not 'make the beginnings of demonstoutivov ófoi

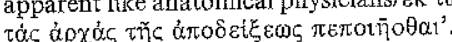

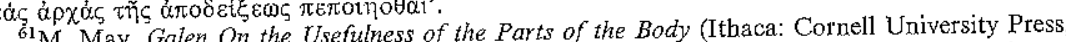
M) Mrovites 6268), provides an extremely usefur comon (Lipsiae: In Aedibus B. Teubner, 1907), III.118. ${ }^{63}$ alen De Usu Partum, G. Heln (Lipsiae: In Aedibus B. Teubner, 1909), ${ }^{63} \mathrm{Ga}$

IV. 350 . 
reducing to masses/ǒ $\gamma$ Kous and void' ${ }^{65}$ In one case, Asclepiades disparages nature for the puzzling structure of the pulmonary vessels, and claims that it supports his metaphysical theory that all aspects of the body can be explained as the result of mechanical interactions of unintelligent particles. Since ancient

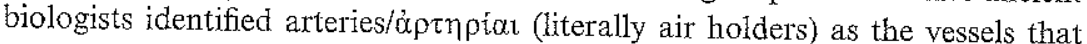
carry pneuma, they dubbed the thin vessel that goes between the lungs and the left ventricle the venous artery (our 'pulmonary vein'); while they called the thick vessel that carries dark red blood from the right ventricle to the lungs the arterial vein (our 'pulmonary artery'). Asclepiades attributes these vessels' unusual character to the mechanical effects of the lungs' motion on their walls. Asclepiades assumes that the venous artery and its branches pulse like every other vessel coming off the left ventricle while the arterial vein would have no vascular pulsation. The additional exercise from respiratory activity causes the arterial veins to obtain thick artery-like walls; but the venous arteries, which already strain with the motion of pneuma, are simply worn out by the second motion and 'toiling excessively they are made very thin' ${ }^{66}$ Thus, the mere coincidence that they encounter the special motion of the lungs causes the arterial vein and venous artery to have their unique character. In this case the bodily parts seem to respond to their unusual circumstances in a rather undirected and mechanical fashion.

After quoting Asclepiades' account, Galen claims that the reductionist explanation overlooks more significant purposive and even material/tìv of́ov $\dot{u} \lambda u \kappa \eta v$ causation in favor of "causation according to coincidence or from

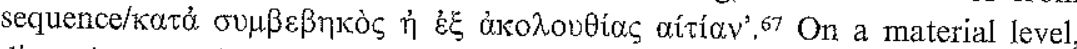
dissection reveals that the venous artery is thinner than the ones coming off the aorta because it lacks the inner tunic found in other arteries, while the arterial vein has the three tunics normally found in arteries. Since the vessels have these properties in the newborns and fetuses dissected or vivisected in utero before the lungs begin moving, their special character must result from some processes natural to the organism, and not from the mechànical motion of breathing. ${ }^{68}$

${ }^{65} \mathrm{Galen}$, op. cit., note 62, III.474. Although none of Asclepiades works are extent, J, T. Vallance (1990) 11 ses references to him in otder to offer a rich reconstruction of Asclepiades' theory, The Lost Theory of Asclepiades of Bithynia (Oxford: Clatendon Press, 1990). Vallance argues that Asclepiades' oykot ate divisible, and that his approach to the body draws much nore from Erasistratus tha Epicurus.

${ }^{66} \mathrm{Galen}$, op. cit., note 62, III.467. ${ }^{67}$ Ibid., III.466. Hankinson interprets Galen's criticism here as simply that Asciepiades offers a
materialistic account that gets the direction of explanation wrong. He claims Galen believes that the venous'arteries 'are not thin because they labor hard, but labor hard because they areves thin' note 27, p. 1853). Yet, Galen also uses anatomical observation to bet the the a thin (op. cit, game with a more accurate account of the body's structure. Strictly matrialist at his ow perspective the venons arteries do not labor much at all, but are ptivis speaking, from Galeu's with the lungs (see Usefulness of the Parts III.449). Furthernore, at Anatomical Proced expanded Galen reports that it is not anatomically determinable whether of at the ver like the other arteries.

${ }^{68}$ See Usefulness of the Parts III.474.
Furthermore, other organs, like the heart, that also move constantly do not have venous arteries and arterial veins as Asclepiades' theory would predict. Galen argues that the pulmonary vessels have their special structure because it better enables them to fulfill their usefulness to the whole organism. In Galenic physiology the arterial vein delivers vigorous spirited blood that would burst ordinary thin veins from the right ventricle to the lungs, and must be thick and strong enough to resist compression from the lungs. On the other hand, the venous artery must be thin enough both to take in pneuma from the air on inhalation and to allow the lungs to push this pneuma into the left ventricle when they collapse with exhalation. ${ }^{69}$ When observed in anatomical practice, the structure of the pulmonary vessels thus shows that 'there is purpose arranging and ordering all these, not masses of bodies clinging to one another

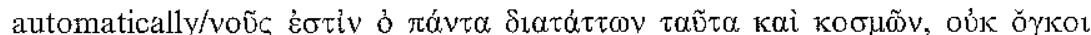

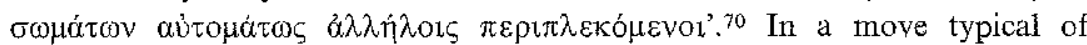
Usefulness of the Parts, Galen uses further details revealed about phenomena from experimental anatomy to turn a reductionist's example of the body's blindness into a case of nature's craft.

Galen's reverence for nature takes on ethical dimensions. ${ }^{71}$ After considering someone who held that it would have been better if the urethra opened in the foot so that he could urinate without getting the rest of his body out of bed, Galen sermonizes:

What then do you suppose this person feels or does alone?, or how does he treat with insolence all the orifices of his body?, or how has he both insulted and lost the most beautiful aspect of his soul, by which alone man is naturally able to witness truth, having made its divine power crippled and altogether blind, while making great strong, and insatiate of wrongful pleasures the most brutal power that unjustly tyrannizes the weak? ${ }^{72}$

Galen thus traces distespect for nature to a beastly urge for material luxury. In his moral psychology, he accepts the Platonic analysis of the human soul into

${ }^{69}$ Because it is somewhat different from our current conception of circulation, Galen's cardioyascular physiology seems enigmatic to the 20th century mind. Recognizing the valves of the heart and great vessels, Galen believes that blood flows from the left ventricle into the lungs, and that an excessive blood continues through microscopic connections between the veins and arteries, and ultimately in to the right ventricle (see Usefulness of the Parts III.444-457). Unlike 20th century biologists, however, he seems to believe that most of the blood that passed to the lungs from the right ventricle is consumed by the lungs as nourishment. Nonetheless, May thinks that we can credit Galen with 'a very rudimentary conception of a pulmonary circulation', op. cit., note $61, \mathrm{p} .301$ Although biology has rejected pneuma theory, it still agrees with Galen that the different vessel thickness serves a purpose. The pulmonary artery needs to be thick enough to withstand the high pressured blood pumped out of the right ventricle, while the pulmonary vein needs to be thin enough to teceive low pressure blood from the lungs.

enough to receive low pressu

${ }^{71}$ For a general account of the close relation between ethics and science in antiquity see Lloyd, op. cit., note 8. C. Cosans, "Anatomy, Metaphysics, an Values: the Ape Brain Debate Reconsidered', Biology and Philosophy 9 (1994),129-165, offers a case study of the extent to which even modern anatomy is inextricably linked with values.

${ }_{72} O p$. cit., note 62 , III. 337 . 
the three aspects: the rational centered at the brain, the passionate centered in the heart, and the desiderative soul that emanates from the liver. ${ }^{73}$ In an allusion to the Phaedrus, Galen holds that if one has strength and science/ ' $\pi$ $\pi \tau \eta$ r Since the irrational lower psyches are very powerful in children, one must try to strengthen the rational soul through education in order to become a good person. Hence the knowledge obtained by experimental biology can take on an almost sacred dimension. Indeed, Galen explicitly contrasts his experiments with temple animal sacrifices, and claims he most truly worships our creator 'if I would learn myself first, and then show the way to others, what is his wisdom, power, and uprightness'. ${ }^{75}$ Experimental anatomy allows the unbiased observers to witness a divine presence amidst our very flesh.

In a careful theoretical study, Hankinson uses Galen's elementary account of the elephant's trunk to analyze his teleology in theistic terms. ${ }^{76}$ Throughout his study, Hankinson refers to Galen's object of praise as the 'Creator', following

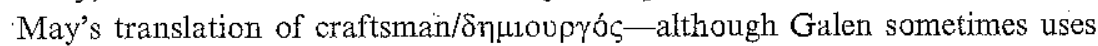
this term interchangeably with nature/púols. Hankinson portrays Galen as embracing an undiluted teleology:

For Galen, it is strictly and literally true that Nature does nothing in vain: and any refusal to accept the implications of that claim, and any attempts to dilute the teleology to make it more palatable, are admissions of weakmindedness, and blemishes on the body of natural science. ${ }^{77}$

Hankinson argues that Galen has a'fundamentalist reading of Plato's Timaeus story, and advocates an even stronger version of teleology than Aristotle. He claims that Galen focuses on the perfection of the body in order to make a theological point that long ago the body's parts 'were consciously arranged like that by an intelligent, benevolent Creator'. ${ }^{78}$ On this view, Galen applies reason to anatomical observations in order to draw inferences about events that occurred long before human experience. Although Hankinson concludes that

${ }^{73}$ In a fragment from his commentary on the Timaeus, Galen further associates the rational soul with the world soul's motion of the same, while tying the passionate and desiderative souls to the motion of the other, see Larrain, op. cit., note 14, p. 50.

${ }^{74} \mathrm{Galen}$, On the Doctrines of Hippocrates and Plato, edited and translated by P. De Lacy (Berlin: Akademie Verlag, 1978), V.303.

${ }^{75} \mathrm{Op}$. cit., note 62 , III.237. Elsewhere Galen desctibes his recurrent laryngeal nerve experiment as 'this mystery which I now practice', ibid., III.576).

${ }^{76}$ See both R. J. Hankinson, 'Galen Explains the Elephant', in M. Mattlen and B. Linsky (eds), Philosophy and Biology (Calgary: The University of Calgary Press, 1988), pp. 135-157, and R. J. Hankinson, 'Galen and the Best of All Possible Worlds', Classical Quarterly 39 (1989), 206-227. Galen uses the example of the elephant's trunk at the conclusion of Usefulness of the Parts. This allows him to follow up the much more detailed accounts in the book's main body, which assume anatomical practice, with an instance where the reader can grasp a part's usefulness with his innagination. The trunk example thus draws upon the reader's practical acquaintance with less exotic anatomical material.

${ }^{77}$ Hankinson, op. cit., 1989, p. 206.

${ }^{78}$ Ibid., p. 216.
Galen makes the strongest argument possible in the context of ancient philosophy, he qualifies Galen's attack on materialism as only working 'in default of something like a theory of natural selection, or in more general terms a cybernetic account of self-regulating mechanisms that exhibit patterns of positive feedback' ${ }^{79}$

Although Hankinson provides excellent theoretical analysis, he sells Galen short in one important respect. Galen's case for nature's purpose works on a much more empirical level than a theologian's logic. In responding to the disputes between Rationalist and Empiricist sects of his time, Galen uses experimental anatomy as part of a critical realism that rejects indulgence in theoretical speculations. ${ }^{80}$ In this realism, classical texts are read with an eye for ways in which they touch upon the truth. While Galen does consider how the body might have been first constructed by a craftsman in the Timaeus mold, more often Galen simply describes how nature crafts each individual's body in the course of development here and now. Insofar as he interprets Plato's craftsman as another way of referring to Aristotle's nature, Galen moves beyond a theism which focuses upon the divinity's action in distant supernatural events, to a pantheism that embodies purpose everywhere. If nature acts with a purpose here and now, one need not rely entirely upon a likely story of past events to support teleology. Hence, Galen takes the epistemological stance throughout the Anatomical Procedures and Usefulness of the Parts that one can directly perceive nature's purpose by touching, seeing, and even tasting the body in anatomical manipulations..$^{81}$ Galen thus warns the reader against taking anatomy at his word: anatomical practice 'alone would be sufficient to make known both the forethought and the marvelous art of the craftsman' ${ }^{82}$ Hence the lengths to which Galen goes to show that Asclepiades' analysis of the lung's venous artery rests on an observational error, and to anchor even his general conclusion with the specific example of the elephant's trunk. Adding

${ }^{79}$ Hankinson, op. cit., 1988, pp. 139-40. Although it is fashionable to assert modern biologists have done away with teleology fully, some scholarship in the history and philosophy of biology questions this assumption. J. Cornell, 'Newton of the Grassblade? Darwin and the Problem of Organic Teleology', Isis 77 (1986), 405-421, examines why Datwin's theory does not explain away teleology, while L. Nissen (1993) explains why neither behaviorism, natural selection, metaphor, nor feedback successfully eliminate mind from teleology in 'Four Ways of Eliminating Mind from Teleology', Studies in the History and Philosophy of Science 24 (1993), 27-48. In Cosans, op. cit., note $71, \mathrm{I}$ argue that anatomists must use teleology as an inescapable aspect of the human

perspective.
${ }^{80}$ See Cosans, 1997, op. cit., note 1. At Commentary on Hippocrates' Nature of Man, op. cit., note 45 , XV.133, Galen draws a sharp contrast between what is perceived in anatomy and inferred in

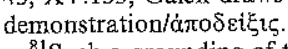

${ }^{81}$ Such a grounding of theology in experience fits well with Galen's auti-speculative philosophy. M. Frede thus notes that Galen refused to take a position on many metaphysical questions, including 'the essence of God', 'On Galen's Epistemology', in V. Nutton (ed.), Galen: Problems and Prospects (London: Wellcome Institute for the History of Medicine, 1981), pp. 65-85, see p. 84. Given his ever presence, the Demiurge appears in Galen's exploration of the difference between willed and natural movements, Larrin, op. cit., note 23 , see pp. 181-182.

${ }_{82}$ Op. cit., note 63, III.720. 
more characters to the materialist's story, be they Natural Selection or crocodiles, only makes the theory more distant from human experience. Galen objects to materialists not because their interpretation of nature lacks theoretical sophistication, but because they are simply unperceptive/

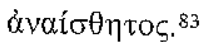

Galen writes the Procedures in order not to rest the case for teleology entirely on speech, but to enable the student of nature to observe nature's purposiveness at the workbench. His approach fits well with what some recent historians and philosophers of science teach us about the epistemology of experiments. Galen pens his accounts not as self-sufficient linguistic descriptions, but to help his readers reproduce and witness the effects of his procedures with manipulations of their own. Gooding provides an excellent account of experimental scieice's reliance upon such active manipulation on the part of the student. In addition to linguistic and mental theorizing, he argues that a scientist also 'construes visual and sensorimotor experience by ordering spatio-temporally discrete' 84 objects and actions. These construals yield 'practical facts'85. which depend on the embodied context of action. Although scientific texts themselves are linguistic representations, they thus rely upon material manipulations of nature that the scientifically trained reader must follow and perform. In his case for scientific realism, Hacking further suggests that scientists must come to believe in the reality of the entities that they experimentally manipulate. ${ }^{86}$ From Galen's point of view, if the philosopher of nature enters into the cognitive state of actively operating upon organic bodies, he will no longer question whether nature generates the parts of animals with purpose. The anatomist moves beyond theoretical analysis, and puts teleological philosophy on an experimental foundation.

Acknowledgements-I would like to thank the many people who have discussed the various ideas of this paper. R. J. Hankinson, R. Richards, E. Asmis, A. Schoener, E. Langston M. Mahowald, E. Sageng, N. Maistrellis, D. Millett, L. Daston, W. Wimsatt, M. Forster, an anonymous referee from this journal, and A. Cosans have read previous drafts and offered many helpful suggestions I am especially indebted to my colleague Mike Frampton, with whom I followed Galen's directions for monkey dissection in the Anatomical Procedures on a wath whom I follow

${ }^{83}$ In On Puzzling Movements, Galen criticizes those who either fail to grasp the importance of perception or the fact that nature does nothing in vain as not being properly educated in science, Larrin, op. cit., note 23 , p. 189.

${ }^{84} \mathrm{D}$. Gooding, Experiment and the Making of Meaning (Dordrecht: Kluwer Academic Publishers, 1990), p. 63.

${ }^{86}$ Op. cit., note 7, pp. $262-275$

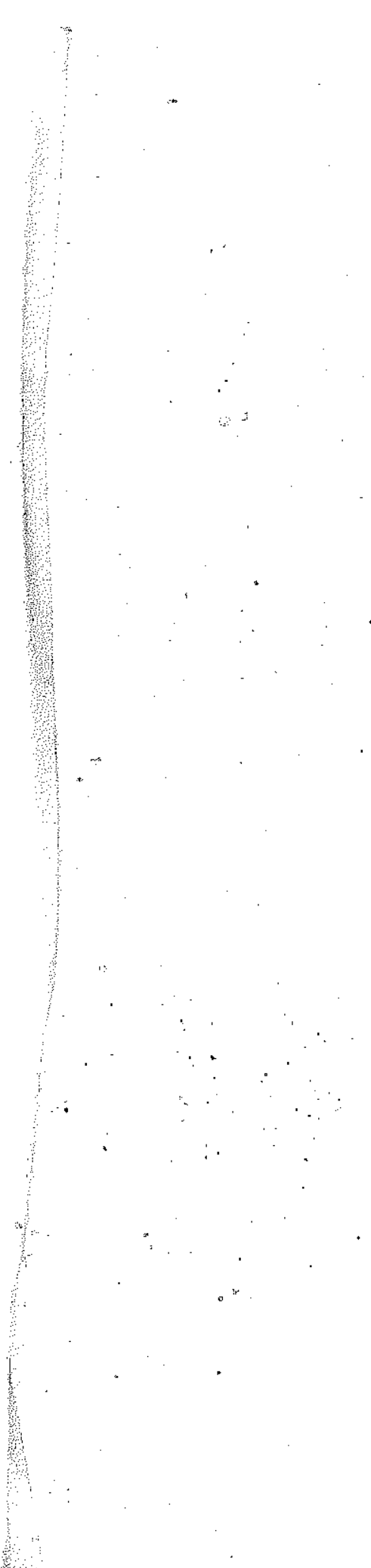

